„Przekłady Literatur Słowiańskich”. T. 9, cz. 3

ISSN 2353-9763 (wersja elektroniczna)

DOI $10.31261 /$ PLS.2019.09.03.23

\title{
Od romanov do teoloških esejev: pregled slovenskih prevodov poljske literature v letu 2017
}

\author{
From Novels to Theological Essays: \\ Review of Slovene Translations \\ of Polish Literature in 2017
}

\author{
Jana Unuk \\ iD https://orcid.org/0000-0003-3649-0323 \\ LJUBLJANA \\ janaunuk@gmail.com
}

Data zgłoszenia: 13.10 .2018 r. ｜Ｄata akceptacji: 30.11.2018 r.

\begin{abstract}
The article deals with translation choices by Slovene translators from Polish literature in 2017, on the presumption that both literatures, that of source and that of the target language, perceive each other as peripheral in terms of Even-Zohar's theory of literary polysystems. Nevertheless, as much as 14 Polish books of different genres were translated into Slovene language in 2017, among them novels, poetry, a play, and theological essays.

KEYWORDS | peripheral literatures, Polish-Slovene translations in 2017, translation choices, genre diversity
\end{abstract}


Normalna pozicija prevodne literature je po Itamarju Even-Zoharju ${ }^{1}$ na obrobju 242 literarnega polisistema. ${ }^{2} \mathrm{~V}$ njegov center se lahko premakne samo, kadar se polisistem še ni kristaliziral (t. i. »mlada« literatura); kadar je literatura periferna (znotraj večje skupine povezanih literatur) ali šibka; ob preobratih, v kriznih trenutkih v zgodovini literature ali kadar nastopi nekakšna literarna praznina. Še obrobnejši, vendar zato s stališča prevajalca svobodnejši in vznemirljivejši, manj podvržen pritiskom tradicije, norme in kanona, je položaj literarnega prevoda, kadar ta poteka med dvema literaturama, kakršni bi po Even-Zoharju potencialno lahko imenovali periferni, ${ }^{3}$ poljsko in slovensko. Če je v zgodovini v skladu s predstavljenim modelom slovenska književnost veliko sprejemala iz nemške in če v sodobnosti večina evropskih literatur s prevodi največ sprejema iz angleške, pa se danes vse bolj uveljavlja tudi prevajanje med (tudi manjšimi) evropskimi jeziki. To težnjo Andrej Blatnik za Samirjem Aminom imenuje evrocentrizem $^{4}$ in je mdr. posledica politične podpore tovrstnemu prevajanju znotraj Evropske unije (program Ustvarjalna Evropa, nagrada EU za književnost). Še vedno se v slovenščino, podobno kot v druge evropske jezike, največ prevaja iz angleščine. Tudi ko isti avtor ugotavlja, da Slovenci prevajamo zlasti komercialno leposlovje, ki nam ga samim primanjkuje, in izvažamo kakovostno, ${ }^{5}$ se to prejkone nanaša na izmenjavo $\mathrm{z}$ angleškojezično literaturo. Ugotavljamo namreč lahko, da praktično vsa izmenjava med slovenščino in poljščino poteka na ravni kakovostne literature. Razloge bi lahko poiskali v relativni obrobnosti mesta izhodiščne literature znotraj literarnega polja ciljne, omejenosti naslovnikov na ožji krog poznavalcev in nemožnosti komercializacije prevodov. Pri tem obe ciljni kulturi tudi zaznavata druga drugo kot periferni. Anna Muszyńska Vizintin sicer tudi za prevajanje iz poljščine v slovenščino predpostavlja »ome-

1 I. Even-Zohar, 2009: Miejsce literatury tlumaczonej w polisystemie literackim. V: P. Bukowski, M. Heydel, ur.: Współczesne teorie przekładu: Antologia. M. Heydel, prev. Krakov, Znak, str. 202.

2 Teorija polisistemov Even-Zoharja obravnava dinamiko in heterogenost kultur, njihov soobstoj, součinkovanje in medsebojne vplive. Gl. M. Heydel, 2009: Itamar Even-Zohar (ur. 1939). V: P. Bukowski, M. Heydel, ur.: Współczesne teorie..., str. 195.

3 Po Even-Zoharju so "na zahodni polobli periferne literature zelo pogosto istovetne z literaturami manjših narodov, zatorej moramo, čeprav se ta koncepcija utegne zdeti neprebavljiva, ugotoviti, da so bila znotraj z razmerji povezane skupine nacionalnih kultur - na primer v skupini evropskih literatur - hierarhična razmerja določena že vse od začetka. V okviru takšnega (makro)sistema so nekatere kulture privzele periferno pozicijo, kar pomeni, da so se pogosto $\mathrm{v}$ znatni meri izoblikovale na podlagi modelov tujih literatur.« Gl. I. Even-Zohar 2009: Miejsce literatury tłumaczonej..., str. $199-200$.

4 A. Blatnik, 2017a: Prevodno leposlovje v sodobni Sloveniji. »Knjižnica«, 61/4, str. 51.

5 A. Blatnik, 2011: Bo še šlo brez Nobelove?»Pogledi«, 23. Dostopno na: http://pogledi. delo.si/knjiga/bo-se-slo-brez-nobelove [obiskano: 1.10.2018]. 
jeno svobodo prevajalčeve izbire« zaradi komercializacije založniškega trga, ${ }^{6}$ vendar bi v resnici težko govorili o možnostih za komercialno uspešnost ali neuspešnost poljskega prevodnega naslova na slovenskem trgu. Ta misel lahko igra kakšno vlogo kvečjemu v neki predhodni fazi odločanja, namreč o tem, ali sploh uvrstiti v program delo katerega od poljskih avtorjev. Pri tem za odločitev za poljske avtorje danes govori potreba po razgibanem »evropskem « programu. Iz poljščine prevedena literatura s komercialnim učinkom pa se praktično ne zdi mogoča. ${ }^{7}$ Čisto hipotetično bi si, ob vse večji vlogi katoliškega založništva, ki razpolaga s širšimi krogi bralstva, kvečjemu lahko zamislili porast neke bodoče komercialne katoliške literature, recimo povezane z Janezom Pavlom II. Komercialnost prevodov se v Sloveniji pač izčrpa predvsem $\mathrm{z}$ angleško, deloma nemško in morda še kakšno zahodno literaturo. Zato lahko Niko Jež ugotavlja, da se nabor slovenskih prevodov v grobem ujema s poljskim literarnim kanonom, kar tako rekoč že samo po sebi suponira visoko raven teh del: »Ne spreminjajo pa se bistveno merila prevajalskega izbora, na situ prevodnih programov slovenskih prevajalcev in založnikov se slej ko prej obdržijo estetsko zahtevnejša dela in tisti prvenci, ki jih je kritika ocenila kot nesporno pomembne dogodke. ${ }^{8}$

Iz povedanega sledi, da urednik, če se odloči za izdajo poljskega avtorja, od prevajalca ne pričakuje, da mu bo predlagal uspešnico, ampak se prej zaveda, da bo izdal delo po svojem okusu in svoji ali prevajalčevi izbiri za ožji krog poznavalcev. Še vedno se zaveda, da knjiga ni samo tržna vrednost, ampak tudi kulturna vrednota. ${ }^{9}$ Tudi dejstvo, da so takšni prevodi praviloma subvencionirani, pogojuje izbiro kakovostnih del. Torej - paradoksno - slovenskim prevajalcem iz poljske literature relativno svobodo izbire zagotavlja ravno obrobni položaj njihove izhodiščne literature v slovenski percepciji, saj so prevajalci iz večjih jezikov pod večjim pritiskom potencialne komercialnosti, in, ne nazadnje, zaupanje urednikov. ${ }^{10}$

6 A. Muszyńska Vizintin, 2016: Przekłady literatury polskiej w Słowenii w 2015 roku. »Przekłady Literatur Słowiańskich«, zv. 7, 2. del, str. 188.

7 Niti velik prodajni uspeh poljskih literarnih del na poljskem knjižnem trgu (pri tem mislim predvsem na Olgo Tokarczuk in Doroto Masłowsko) namreč ne zagotavlja prodora na slovenskem, kjer ista dela ostajajo prejkone na obrobju zanimanja.

8 N. Jež, 2017: Nova dinamika slovenskega prevajanja iz poljske književnosti v zadnjih desetletjih. »Jezik in slovstvo«, 2-3/LXII, str. 68.

9 Gl. A. Blatnik, 2017b: Vredno je, čeprav je brezplačno. "Literatura«, 316/XXIX, str. 116.

10 Dolgoletni urednik Andrej Blatnik prevajalcem pripisuje veliko vlogo pri precejanju, tj. izbiri knjige, in njenem ojačevanju, tj. pri skrbi za njeno odmevnost (termina M. Bhaskarja), saj so: »[...] prevajalci verjetno bolje od urednikov seznanjeni z literarnim dogajanjem $\mathrm{v}$ manj razširjenih jezikih (dandanes pa so to skoraj vsi jeziki razen angleščine), hkrati pa tudi (drugače od agentov) poznajo domače literarno polje, kar je za izbiro seveda pomembno.« A. Blatnik 2017a: Prevodno leposlovje v sodobni Sloveniji. »Knjižnica«, 61/4, str. 53. 
Problem, ki danes ne zadeva samo knjig, prevedenih iz poljščine, ampak vso prevodno in tudi izvirno literaturo, pa je izgubljanje posameznih naslovov v knjižni hiperprodukciji in posledično hitro pojemajoča odmevnost knjige, v najslabšem primeru njena neodmevnost. $V$ zadnjih letih je mogoče spremljati število izposoj v javnih knjižnicah, ki so pomemben način dostopa bralcev do prevodne literature, in ta podatek pokaže, da je število izposoj daleč največje $\mathrm{v}$ prvih mesecih po izidu ter nato $\mathrm{z}$ vsakim letom bistveno upada. Knjiga, še zlasti beletristična, vse hitreje zastareva in od obilice novih naslovov ${ }^{11} \mathrm{dez}-$ orientirano, če ne kar naveličano bralstvo, ki lahko alternativno obiskuje tudi številne literarne prireditve, ${ }^{12}$ hlasta po novostih in spregleduje že pol leta stare naslove, kar knjigo v nekem smislu spreminja v pokvarljivo robo za hitro, da ne rečemo enkratno potrošnjo. Presenetljivo to velja celo za dela s statusom klasike ali sodobne klasike.

Leto 2017 je bilo, sodeč po številu objavljenih knjig, prevedenih iz poljščine, izjemno uspešno, saj se s 14 knjižnimi naslovi ${ }^{13}$ uvršča tik za rekordnim letom 2015, ko je bilo objavljeno kar 16 knjig. V »običajnejših « letih se knjižni izkupiček giblje med 6 in 8 naslovi (za ponazoritev: 2013 sedem, 2014 osem, 2016 šest). Prevode je podpisalo kar 8 prevajalcev: sama sem prevedla 5 del, po dve sta prevedli mlajši prevajalki Staša Pavlović in Lara Unuk, pet prevajalcev po eno. Zvrstno je prevodna bera presenetljivo raznolika, saj obsega 5 romanov ( 3 prevajalke), 3 novelistične zbirke (ena prevajalka), 2 knjigi poezije ( 2 prevajalca), 3 dela s področja mladinske in otroške literature (3 prevajalci), eno esejistično delo in eno dramo. Večina (11) del je sodobnih, od tega jih je 10 (tj. kar $71 \%$ vseh prevodov) nastalo v 21. st., eno pa v 90. letih 20 . stoletja. Preostala tri so nastala v 20. stoletju: eno sodi v literarnozgodovinsko formacijo modernizma 30. let, en avtor je prav tako predvojni modernist, ki je

11 Kot je razvidno iz objave na strani Statističnega urada Republike Slovenije z 19. 4. 2018, se število izdanih knjig po podatkih NUK po obdobju naraščanja v letih 1991-2011 že vse od leta 2011 zmanjšuje, vendar pa delež naslovov leposlovja med njimi, nasprotno, narašča. V 2016 je izšlo manj knjig (5319) kot v 2015 (5411), odstotek leposlovnih naslovov med njimi pa je v letu 2016 znašal $34 \%$, tj. $3 \%$ več kot v letu 2015. Dostopno na: https://www.stat.si/StatWeb/News/Index/7360 [obiskano: 1.10.2018]. Zadnji znani podatki se nanašajo na leto 2016.

$12 \mathrm{Na}$ isti strani je bil 16. 8. 2018 priobčen podatek, da je bilo leta 2017 v Sloveniji povprečno 60 prireditev vsak dan, od tega je bilo predavanj in literarnih prireditev 6,6\%, tj. skoraj 4 dnevno. Dostopno na: https://www.stat.si/StatWeb/News/ Index/7581 [obiskano: 1.10.2018].

13 Lani izdanih elektronskih knjig ne upoštevam, ker so bile to bodisi elektronske različice v prejšnjih letih izdanih tiskanih knjig (Różewicz, Miłosz in Herbert pri Hiši poezije, Lem pri založbi KUD Police Dubove) ali pa so izšle hkrati s tiskano knjigo (Tokarczuk, Karpowicz pri založbi KUD Police Dubove). 
pisal še tja do 80 . let, eno pa je iz 70 . let. Vsa dela razen dveh so bila prevedena iz poljščine.

Da je bilo prevedeno največ romanov ( $36 \%$ produkcije), ne preseneča, saj je po tej književni zvrsti največ povpraševanja in med uredniki velja za najmanj tvegano odločitev. Prejkone je delež romana v prevodni literaturi zadnjih let nasploh še višji. Izjemno pozitivni so bili odmevi prvega prevedenega dela Joanne Bator Peščena gora (prev. S. Pavlović), ki je izšel pri novomeški založbi Goga. Roman popisuje življenje več generacij povojnih priseljencev iz predvojnih poljskih mejnih krajin, današnje zahodne Ukrajine, v rudarsko mesto Wałbrzych v Dolnji Šleziji. Deležen je bil vsaj treh naklonjenih recenzij, in sicer ene izpod peresa vidnega literarnega kritika Mateja Bogataja $v$ osrednjem političnem tedniku Mladina, drugih dveh pa na spletnem portalu AirBeletrina in po radiu Študent. ${ }^{14}$ Ker roman pripoveduje o treh generacijah žensk, so slovenska branja v njem opažala predvsem feministične, idejno napredne in družbenokritične tendence, vendar niso spregledovala avtoričinega slogovnega mojstrstva in pretanjenega občutka za jezik. Občudovanje pisateljičine jezikovne umetelnosti, spretnosti v stopnjevanju srhljive orkestracije in slikanju psiholoških globin, tudi nezavednega, ter žanrske in idejne kompleksnosti njene proze ni bilo nič manjše, ko je čez slabega pol leta (že v letu 2018) izšel mračnejši in recepcijsko zahtevnejši roman Temno, skoraj noč (nagrada nike 2013). Recenzije slednjega praviloma navezujejo na branje prvega romana, presenetljivo pa je, da generaciji mladih kritikov očitno bolj spregovarjajo žanrske kvalitete dela (srhljivost, detektivski motivi) kot njegova izjemno zadeta politična ost, ${ }^{15}$ izražena mdr. $\mathrm{s}$ satirično-groteskno upodobitvijo manipulacij $\mathrm{z}$ množico, prepričljiva tudi zaradi bogate diferenciranosti stilističnih sredstev in upovedovanega govora, v ključnih momentih razgrajenega v blebet.

Najobsežnejše delo lanske sezone je bil zgodovinski roman Olge Tokarczuk Jakobove bukve (prev. J. Unuk) z dobrimi 56 avtorskimi polami in $936 \mathrm{stranmi}$ v tiskani izdaji. Izšel je pri založbi KUD Police Dubove avgusta 2017, tri leta po izidu originala 2014, kot tretji prevod tega romana v svetovnem merilu, za švedskim in češkim ter malo pred srbskim izpod peresa M. Markić (jesen 2017), slabo leto pred hrvaškim izpod peresa M. Martića (poletje 2018) in francoskim (september 2018, prev. M. Laurent). Pred izidom je hebrejski prevod, knjiga

14 Ker slovenski časopisi in literarne revije $\mathrm{v}$ zadnjem času recenzirajo skoraj izključno izvirno literaturo, je izkupiček dveh, treh recenzij več kot soliden.

15 Ana Geršak v kritiki Zlo bo vstopilo brez trkanja (Dnevnik, 9. 8. 2018) dojema groteskno-politično komponento romana celo kot odvečno obremenitev dogajanja. Dostopno na: https://www.dnevnik.si/1042835716 [obiskano: 1.10.2018]. Temno, skoraj noč so izjemno pozitivno recenzirali še v Bukli in na spletni strani Koridor (Martin Justin), obakrat uvodoma navezujoč na prvo, 2017 prevedeno delo. 
pa se prevaja še v številne evropske jezike (mdr. v nizozemščino, madžarščino, angleščino). Veliki razmiki med objavami originala in prevodov opozarjajo na zahtevnost in dolgotrajnost prevajanja, saj je Olga Tokarczuk sicer ena od najbolj ažurno prevajanih poljskih pisateljic. Sama sem se za prevajanje tega obsežnega romana odločila že takoj po njegovem izidu, in sicer iz dveh razlogov. Prvič, kolikor je mogoče sistematično, prevajam knjige Olge Tokarczuk že od časa, ko avtorica še ni bila poljska in evropska literarna zvezda, ampak mlada avtorica iz moje generacije. Njeno prvo v slovenščino prevedeno delo, Dnevna hiša, nočna hiša, je res izšlo šele leta 2005 (še istega leta je sledil Pravek in drugi časi v prevodu Jasmine Šuler Galos), po nekaj letih dogovarjanj in selitev med založbami - vendar sem avtorico spremljala od njene prve knjige. K Jakobovim bukvam pa me je pritegnila tudi tematika, fascinantna zgodovina in nauki židovskih verskih in duhovnih gibanj na ozemlju historične Poljske, s čimer sem se že prej prevajalsko ukvarjala (mdr. s prevodi I. B. Singerja in Filipa Davida).

Šele med prevajanjem sem sklenila, da bom slovenski naslov knjige iz nevtralne slovenske oblike Jakobove knjige spremenila v Jakobove bukve, ${ }^{16} \mathrm{kar}$ bolje ustreza tako poljskemu izrazu księgi kot historični vsebini in stilizaciji besedila. $S$ tem sem lahko dosegla podoben učinek, kot ga je, recimo, srbska prevajalka z zapostavo pridevnika, ki v slovenščini ni mogoča, in uporabo bolj starinske od obeh možnih oblik svojilnega pridevnika iz imena Jakov (tj. Jakob), "Jakovljev" (Knjige Jakovljeve), ali hrvaški prevajalec samo z zapostavo pridevnika (Knjige Jakubove). Ker je bila oznaka »bukovski jezik« nekdaj sinonim za latinščino, se zdi naslov še posebej ustrezen za tekst, v katerem je stilizirana verzija poljskega zgodovinskega jezika, npr. v fiktivnih pismih enciklopedista dekana Chmielowskega, pod zelo močnim vplivom latinskega besedja in sintakse.

Za roman je značilno izmenjevanje dokumentarnosti in fikcije, opisov zgodovinsko izpričanih prizorov in nerazkritih citatov avtentičnih historičnih tekstov s fiktivnimi scenami in besedili. Pisateljica je v njem ohranila značilni fragmentarizirani način pripovedovanja (t. i. »konstelacijski roman «), ${ }^{17}$ in čeprav $\mathrm{v}$ pripovednem toku zvesto, celo kronološko sledi zgodovinskemu dogajanju, povezanemu s frankisti, in biografiji preroka Jakoba Franka, se ni odpovedala svojim stalnim aktualnim temam, temveč je svoje junake v nekem smislu obdarila $\mathrm{z}$ moderno občutljivostjo ter $\mathrm{v}$ zgodovinsko tkivo romana vkomponirala problematiko feminizma, odnosa do drugega in drugačnega, večnacionalnosti

16 Starinske besede »bukve« $\mathrm{v}$ slovenščini še ni prerasla pretirana patina in jo izobraženi bralec mora poznati, poleg osnovne tudi v oblikah, kot sta npr. »(mašne) bukvice« ali pogovorna "bukla«. Etimološko beseda izhaja iz stcsl. buky, gen. bukzve v pomenu »črka«; množina je izpričana v r. csl. bukovø »črke«. Gl. F. Bezlaj, 1976: Etimološki slovar slovenskega jezika A-J. Ljubljana, SAZU-MK, 1. zv., str. 53, geslo »bukve«. Termin Olge Tokarczuk. 
in socialne razslojenosti družbe ter hegemonije vladajočega naroda in razreda, predvsem v poljskih vzhodnih mejnih krajinah. S tem je podrezala v sprejeto literarno samopodobo poljske družbe, kot pravi sama, ob popolnem zavedanju dejstva, da je »obvezujoča zgodovinska naracija nekaj, kar je skonstruirano in se vedno znova konstruira «. ${ }^{18}$

Leto dni po izidu se dozdeva, da je knjiga s tolikšnim obsegom za slovenske bralce kljub vsemu trd oreh in da potrebujejo kar nekaj časa, da se prebijejo skoznjo. Tisti, ki jim je to uspelo, so kvalificirani bralci in cenijo tako informacije o Slovencem povsem neznanem pojavu frankizma kot univerzalno sporočilo knjige. Olga Tokarczuk ima tudi sicer v Sloveniji svoje zvesto občinstvo. Širše zanimanje je zbudil roman Pelji svoj plug čez kosti mrtvih, predvsem zaradi etičnega sporočila, tj. zagovora pravic živali. ${ }^{19}$ Zaradi obsežnosti in teže romana je več odmeva Jakobovih bukev pričakovati še v naslednjem letu, zlasti ob načrtovanem gostovanju avtorice. Doslej je o knjigi objavila recenzijo pisateljica in prevajalka Miriam Drev na RAI v Trstu, izšla pa sta tudi dva članka Ane Geršak: kritika knjige na Radiu Slovenija in na portalu MMC ter članek ob avtoričinem prejemu nagrade booker international v Dnevniku, v katerem obravnava vse doslej prevedene knjige Olge Tokarczuk s poudarkom na že leta 2010 prevedenih nagrajenih Begunih. Tudi Ana Geršak poudarja predvsem družbeno-socialno komponento frankistične zgodbe ter univerzalno in etično sporočilo romana:

S slikanjem usode poljskih Judov, ki so se med letoma 1759 in 1790 pod vodstvom Jakoba Franka odločili za prestop v katoliško vero, Olga Tokarczuk raziskuje pojav ksenofobije in antisemitizma v vzhodni Evropi. [...] Družbeni sistem, kot ga slika Olga Tokarczuk, je zgrajen na logiki, da bo prišlek - ali tujec - vedno na zgubi, ker bo vedno zaznamovan s svojo tujskostjo. V luči vsega, kar se danes dogaja na Poljskem in tudi v Evropi, je težko spregledati skrajno družbenokritično ost romana. Jakobove bukve, ta véliki roman z začetka 21. stoletja, so resnično izjemno delo. ${ }^{20}$

S takšno interpretacijo deloma sledi sami zasnovi romana, v katerem bolje dokumentirano zunanje dogajanje ni vedno uravnovešeno $\mathrm{z}$ religiozno-mistično

18 O. Tokarczuk, 2014: Jak powstały »Księgi Jakubowe«. Dostopno na: http://wyborcza. pl/1,75410,17154801,2014_rok_wedlug_Ksiazek__Tokarczuk_Jak_powstaly.html [obiskano: 20.03.2018].

19 Jelka Kernev Štrajn ga je na primer obravnavala v študiji Zoper »naravni« red sveta (v: »Primerjalna književnost«, 2/2016, str. 71-88) kot primer tematizacije neantropocentrične naravnanosti, ki se izraža v odnosu do okolja in živali.

20 A. Geršak, 2018: Olga Tokarczuk, poljska pisateljica: Na novo pisati svet. "Dnevnik«, 18.07. Dostopno na: https://www.dnevnik.si/1042833368 [obiskano: 20.07.2018]. 
vsebino sektarskega duhovnega nauka, kar verjetno izvira iz tega, da nobeno ezoterično izročilo ni $\mathrm{v}$ celoti zabeleženo, mistično doživetje pa ne racionalno dosegljivo in verbalno izrazljivo.

Roman Ignacyja Karpowicza osti (prev. Jana Unuk, KUD Police Dubove) je po Baladinah in romancah drugo delo tega avtorja pri nas. Kot že avtorjeva prva prevedena knjiga je ta zameštrana štorija o naravnost fantastično razširjenih, toda funkcionalnih družinah, $\mathrm{v}$ katerih je vse možno in ni nikomur kratena nobena osebnostna in iz razlogov rase, spola, spolne orientacije, narodnosti ipd. izvirajoča pravica, žela tako navdušenje kot zadržanost in kritiko, predvsem iz ideoloških razlogov. Tako kot že prvo knjigo je tudi to naklonjeno bral Matej Bogataj v Mladini, o njej pa sta pisala še Urška Gabrič na spletni strani LUD Literature in Dejan Mohorič na radiu Študent. Noben recenzent ni spregledal avtorjeve slogovne in jezikovne bravuroznosti, je pa recenzent radia Študent njegov svet občutil kot zaprto okolje privilegiranih varšavskih intelektualcev, ki se ob vsej občutljivosti glede lastnih pravic kruto posmehujejo predstavnici tradicionalnih vrednot in spregledujejo družbeno pogojenost razmerij v sodobnem svetu. Očitke Karpowiczevim romanom je mogoče izrekati tako s stališča katoliško-tradicionalne morale (to stališče je zavzela zlasti ena od recenzij $B a$ ladin in romanc v letu 2013) kot iz zornega kota zvestobe socialni stvarnosti, ki je ne odseva elitnost karpowiczevskega miljeja. Vendar bi težko spregledali etično komponento v Karpowiczevem delu, saj bralca še dolgo preganja presunljivi opis pogina mačka ali samotne smrti pogrešanega ljubimca enega od protagonistov. Pisateljeva empatičnost pa se kaže tudi v njegovem odnosu do junakov $\mathrm{z}$ vsemi posebnostmi in čudaštvi, ki jih prikazuje z blagim humorjem. Od ljubezenskih zvez v osteh so daleč najbolj prepričljiva homoerotična razmerja, zato morda utirajo pot prevodu bolj izpovedne in ekspresivnejše Ljubezni (2017).

Kar tri novelistična dela $\mathrm{v}$ enem letu so prej izjema kot pravilo. Prve so v knjižni zbirki Kondor Mladinske knjige izšle izbrane kratke zgodbe Isaaca Bashevisa Singerja z naslovom Moč teme (izbrala in prev. J. Unuk). To je prvi slovenski knjižni natis novel tega znanega avtorja, nobelovca, pripadnika predvojne varšavske jidiš avantgarde, ki se je, potem ko je na Poljskem že objavil vrsto literarnih tekstov, mdr. svoj prvi, modernistični roman Satan v Goraju, v 30. letih 20. stoletja preselil v Ameriko. $V$ ta pregled ga uvrščam kot poljskega pisatelja, ki je pisal v jidišu v eksilu v Ameriki in se ga $-\mathrm{v}$ skladu z njegovo lastno oporoko - prevaja iz angleščine. ${ }^{21}$ Kot ugotavlja poznavalec njegovih del

21 Singer je sam sodeloval pri vseh prevodih v angleščino, ki jih je posledično štel za druge originale; jidišisti zatrjujejo, da je šlo bolj za predelavo kot za prevod in da je pisatelj ustvaril dva opusa, bolj hermetičnega, učenega v jidišu (kot Ichok Baševis) in dostopnejšega, bolj folklorističnega v angleščini (kot Isaac Bashevis Singer). 
Chone Shmeruk, Singer ne sodi v krog ameriških židovskih pisateljev, temveč izhaja iz tradicije evropske jidiš literature, saj je njegova proza zakoreninjena v poljskih razmerah, tako iz avtorjeve mladosti kot iz različnih zgodovinskih obdobij, njegova maloštevilna dela $\mathrm{z}$ ameriško tematiko pa vedno pripovedujejo o izseljencih iz stare domovine. Dvanajst od dvajsetih izbranih zgodb se dogaja na Poljskem in te je pisatelj umestil bodisi v židovsko četrt predvojne Varšave ali na ožje območje znotraj lublinskega vojvodstva. ${ }^{22}$ Kljub splošnemu konsenzu, da gre za tradicionalnega avtorja, izbor poleg tem vzhodnoevropskega židovstva in za avtorja značilne fantastike izpostavlja nekatere izrazito moderne poteze Singerjeve etike: sočutje in sočutenje z živalmi, razumevanje za žensko željo po študiju v restriktivnem ortodoksnem okolju, spolno transgresijo in homoerotično ljubezen.

Za prevajanje Singerja je zelo koristno poznavanje poljskih realij. Pri odločitvah glede zapisovanja jidiš citatnih besed so mi bili v pomoč poljski priročniki in viri ${ }^{23}$ ter literarna zgodovina jidiš književnosti. ${ }^{24}$ Pri izboru iz desetih angleškojezičnih zbirk, ki so jih podpisali različni prevajalci in uredniki, prihaja do različnih zapisov jidiš citatnih besed ter poljskih ali jidiš krajevnih imen. Nekateri so preprosto napačni, včasih pa mešajo Singerjev varšavski jidiški idiom z oblikami litovskega dialekta jidiša, ki se je uveljavil v Ameriki, čeprav Singer ni pristajal na izbiro litovskega dialekta jidiša za standard. ${ }^{25}$

Sanatorij Pri peščeni uri Bruna Schulza (prev. J. Unuk) je edini med mojimi lanskoletnimi prevodi nastal na pobudo založbe (Beletrine). Dogovorili smo se, da lahko knjigo po lastni presoji dopolnim z izborom drugih, v slovenščino še neprevedenih spisov. Knjiga tako poleg Sanatorija vsebuje še vse revialno objavljene zgodbe iz zapuščine in fragment Gledališče pashe, izločen iz Pomladi, izbor iz esejev (v tem delu sem se odpovedala recenzijam knjig tistih poljskih pisateljev, ki jih slovenski bralci ne poznajo ali na katere so že nekoliko pozabili, vendar sem vključila npr. recenzijo knjige Cvetijo akacije Debore Vogel, ki je bila s Schulzem tudi biografsko povezana), javnih dopisovanj (pisemska izmenjava z Gombrowiczem in Witkiewiczev intervju gotovo lahko računata na zanimanje

22 Prim. S.L. Wolitz, J. Sherman, 2001: Appendix: Bashevis Singer as a Regionalist of Lublin Province. V: S.L. Wolitz, ur.: The Hidden Isaac Bashevis Singer. Austin, University of Texas Press, str. 219-224.

23 Npr. M.J. Sitarz, 1992: Z dziejów jidisz — jednego z języków żydowskich. Krakov, Universitas, ali spletna stran Židovskega zgodovinskega inštituta; http://www.jhi.pl/in stytut.

24 C. Shmeruk, 1992: Historia literatury jidysz. Vroclav-Varšava-Krakov, Zakład Narodowy im. Ossolińskich.

25 Gl. npr. D. Telushkin, 1997: Glossary, Note on Transcription. V: D. Telushkin: Master of Dreams: A Memoir of Isaac Bashevis Singer. New York, William Morrow and Company Inc., str. $345-348$. 
slovenskega bralca) ter krajši izbor iz pisem. Knjiga je opremljena tudi z nekaterimi od ilustracij, ki jih je za prvo izdajo l. 1937 izdelal avtor. Čeprav je zaradi časovne odmaknjenosti nastanka pa tudi stilističnih posebnosti dela pri prevajanju potrebna primerna doza previdnosti in preverjanja, npr. pomenov in registrov besed, je prevajanje Schulza, njegovih dolgih, gladko drsečih period, prevajalski užitek, celo svojevrstno lirsko doživetje, ki v nekem aspektu spominja bolj na prevajanje poezije. Schulzeve opise premen neba, izbruhov svetlobe, poplav luči in metamorfoz večno utripajoče, oživljene snovi bi lahko primerjala samo še s podobnimi liričnimi jedri v prozi Virginie Woolf. Izdaja je razveselila predvsem slovenske ljubitelje Schulza, ki so doslej poznali Cimetove prodajalne, ki jih je v 90. letih prevedla Katarina Šalamun Biedrzycka.

Magdalena Tulli je v Sloveniji ena od najbolj priljubljenih poljskih avtoric, o čemer je pričalo število recenzij že prevedenih del in intervjujev s pisateljico ob njenem gostovanju pred leti. Njena tretja knjiga v slovenščini, Italijanski salonarji, je izšla $\mathrm{v}$ trenutno najbrž edini slovenski zbirki, specializirani za kratke zgodbe, Stopinje, ki izhaja pri LUD Literatura. Knjiga te brezhibne stilistke je prva, v kateri je $\mathrm{v}$ svoje zgodbe, ki naj bi pomagale graditi empatijo med ljudmi, dopustila tudi avtobiografske motive. Podobno kot novele B. Schulza se tudi zgodbe M. Tulli povezujejo v konceptualno celoto, zato nekateri literarni znanstveniki v njih vidijo kratki roman. (Podobno je sicer tudi Schulz zvrstno opredeljeval obe svoji za življenja izdani knjigi.) Italijanske salonarje je takoj po izidu recenziral M. Bogataj v Mladini.

V lanskem letu sta izšli tudi dve prevodni knjigi poezije sodobnih, še živečih avtorjev. Prva, ki je v prevodu Primoža Čučnika izšla pri založbi Šerpa, so Oceani: Izbrane pesmi in izbrana proza Andrzeja Sosnowskega (1959), znanega postmodernističnega pesnika, prevajalca angloameriške poezije in urednika literarne revije Literatura na świecie. Sosnowski je bil že gost Festivala poezije in vina 1. 2012 in takrat je v Čučnikovem prevodu že izšel krajši izbor iz njegove poezije Drugo lahko počaka. Sosnowski je prejemnik številnih nagrad (Silesius 2008 in 2017, "posebna nagrada " Gdynia 2011, Gdynia 2013, več nominacij za nike). Izbrane pesmi so prevajalčev izbor iz poljskega izbora Dożynki (1987-2003) iz leta 2006, drugi del pa prav tako izbor iz lirične proze Nouvelles impressions d'Amerique iz leta 1994, postmodernistične variacije na pesnitev Raymonda Roussela Nouvelles impressions d'Afrique z ilustracijami Henrija A. Zoja, ki skupaj z Rousselovimi navodili za ilustratorja, pretransformiranimi v naslove posamičnih kratkih proz, vzpostavljajo zvezo med obema deloma. Škoda, da prevajalec v izbor ni vključil tudi novejših pesmi, saj je Sosnowski po letu 2003 izdal še nekaj pesniških zbirk. Sosnowski na Poljskem velja za zahtevnega, celo hermetičnega pesnika, slovenska recepcija pa mu pripisuje dokajšnjo razumljivost, kot 
je razvidno iz recenzije Bineta Debeljaka na spletni strani mladih kritikov Koridor:

Pomenska mreža, ki jo gradi Sosnowski, sicer ni tako zelo težavna za razumevanje. Gre za nekakšen Postmodernizem 101, uvodni tečaj ali predavanje, izpostavljene »začetne« točke pa se pokažejo v poskusu vzpostavitve intertekstualnosti, ven bijočih popkulturnih referenc, ki imajo več z življenjem samim kot pa visoka kultura, jasno, ne manjka niti ironična (ne)distanca. Skratka, poskus zaobjeti vse, ampak v nizkih prestavah. [...] Postmodernizem Sosnowskega ni odbijajoč, temveč bi prej lahko rekli, da je prijazen. Bralcu skozi pesmi znova in znova pripravlja lep sprejem, lepo ga vpelje, da mu možnost, da se udobno namesti. Le če bo bralec želel, bosta šla skupaj, pesnik in bralec, pod površino in se tam zadržala. ${ }^{26}$

V okviru Festivala poezije in vina na Ptuju v organizaciji založbe Beletrina je izšla festivalska knjižica z izborom pesmi Julie Szychowiak (1986) Sen pod črto (prev. S. Pavlović). Mlajša poljska pesnica je bila doslej slovenskim bralcem poezije povsem neznana. Izdala je že pet pesniških zbirk in eno knjigo proze ter prejela nekaj pesniških nagrad (»jantarno pero« 2007, Silesius v kategoriji debitantov 2008, nagrada Poljskega združenja založnikov 2008). Prej se je pojavila že $\mathrm{z}$ angleškimi prevodi na portalu Versopolis: European Review of Poetry, Books and Culture, ${ }^{27}$ ki ga skupaj z drugimi festivali vodi založba Beletrina oz. njen zgoraj omenjeni festival kot nekakšno valilnico mladih evropskih pesnikov, ki jim omogoča angleške objave. O izboru pesmi Julie Szychowiak ni mogoče reči ničesar, saj izdaja kot priložnostna ni dostopna v javnih knjižnicah. Podobne iz prejšnjih let (v rokah držim npr. Serijo manjših ran Justyne Bargielske iz l. 2015, $\mathrm{v}$ prevodu iste prevajalke, ki je bila pred časom tudi selektorica festivala) so vsebovale med deset in dvajset pesmi v originalu ter slovenskem in angleškem prevodu.

Pozitivno preseneča, da sta v enem letu izšla kar dva izbora poezije še živečega poljskega avtorja in avtorice, saj je sicer, kar zadeva poezijo, založniško povpraševanje omejeno na najbolj znane pesnike 20. stoletja. Celo znotraj te skupine je izbor skrčen na najbolj znana imena, na srečo v zadnjih letih tudi $\mathrm{s}$ celotnimi zbirkami, in ne samo z izbori kot v preteklosti, medtem ko tako rekoč ni mogoče prodreti z novimi imeni niti z nekaterimi klasiki, ki so že znani po številnih revialnih in radijskih objavah (npr. A. Wat, A. Świrszczyńska,

26 Dostopno na: http://koridor-ku.si/recenzije/andrzej-sosnowski-oceani/ [objavljeno: 1.08 .2018$]$.

27 Dostopno na: http://www.versopolis.com/poet/80/julia-szychowiak [obiskano: 1.10 .2018$]$. 
J. Hartwig itd.). K trditvi Muszyńske Vizintin, da v Sloveniji vsako leto izhajajo predvsem knjige na Poljskem že kanoničnih avtorjev, ${ }^{28}$ lahko dodamo, da to velja predvsem za poezijo, medtem ko ima pri izbiri proze, predvsem romana, prevajalec veliko bolj proste roke in je celo zaželeno, da predlaga vedno nova imena.

Tudi poljske drame se v slovenščino prevajajo redko, saj prevodna dramatika praktično ne izhaja $\mathrm{v}$ knjižni obliki. Zato prevodi dram nastajajo po potrebi, se pravi, ob uprizoritvah. Tako je leta 2017 dramaturginja Darja Dominkuš za predstavo, ki jo je v Prešernovem gledališču Kranj režirala Nina Rajić Kranjac, prevedla $\mathrm{z}$ nike nagrajeno dramo Tadeusza Słobodzianka Naš razred: zgodovina $v$ štirinajstih lekcijah. Ker je vsebina drame specifično poljsko-zgodovinska - in tematika poljskih »sosedskih « zločinov nad Židi v času nemške okupacije in takoj po vojni je zunaj poljskih meja pogosto interpretirana izrazito propagandno, celo v kontekstu neoliberalnega prevrednotevanja zgodovine - je slovenski gledalec prejkone moral iz drame, da bi ta učinkovala, luščiti univerzalnejše plasti in sporočila. Kot spopad ideologij in totalitarizmov 20. stoletja v širšem smislu je uprizoritev recenziral Matej Bogataj v Delu:

Vendar je za nas, kjer je različno motiviranih zgodovin zaenkrat še več, bolj zanimiv tisti segment igre, $v$ katerem se antisemiti postavijo na stran nekakšne nove Evrope in kolaborirajo z Nemci, njihove žrtve, tudi zaradi maščevanja in načelne režimske zaščite judovstva, pa potem sodelujejo $s$ komunističnimi in prosovjetskimi tajnimi službami, tudi prek siceršnjih pooblastil. [...] Vse skupaj se odvrti proti sedanjosti, proti prvim letom tega tisočletja, ko redki preživeli, eni razseljeni, drugi dodobra zapiti in $\mathrm{v}$ krču zaradi obremenilne preteklosti in tretji priklopljeni na teve kanale, počasi odhajajo in se tako končuje tudi spomin in izginjajo zadnje priče turbulentnega in krvavega stoletja, inficiranega z izključujočimi ideologijami in totalitarizmi. ${ }^{29}$

Ker v slovenski literaturi kronično primanjkuje žanrskih del, je razveseljivo, da je v lanskem letu izšel prvi slovenski prevod Dorote Terakowske (Hči čarovnic, E-besede). Knjiga, ki jo je prevajalka Lara Unuk izbrala za prvo predstavitev te avtorice, je od njenih fantastičnih romanov za otroke in mladino najbolj univerzalna in torej primerna za izhodišče za nadaljnje prevode te s številnimi nagradami ovenčane mladinske pisateljice. Da je hitro našla svoje občinstvo, pričajo tako ustno pridobljena mnenja navdušenih bralcev kot recenzija na slovenskem

28 A. Muszyńska Vizintin, 2016: Przekłady literatury..., str. 195.

29 Dostopno na: https://www.delo.si/kultura/ocene/ocenjujemo-nas-razred.html [objavljeno: 13.04.2018]. 
knjižničarskem portalu Dobre knjige izpod peresa Ane Dolinšek. ${ }^{30}$ Dodatna vrednost romana je, da je glavna junakinja deklica, saj na trgu v tej starostni kategoriji prevladujejo deški junaki, in upamo lahko, da bomo v naslednjih letih v slovenščini dobili še katerega od mladinskih romanov Terakowske. Obe deli s področja otroške književnosti, Vprašanja iz kopalnice Krystyne Lipka-Sztarbałło in Neymar: nogometni čarodej Dariusza Tuzimka, sta bolj priložnostni oziroma potencialno komercialni izdaji, prva didaktična in druga biografska. Avtorico Vprašanj iz kopalnice smo sicer že spoznali kot odlično ilustratorko Sanj, ki so odšle Anne Onichimowske.

Vse več prevodov iz poljske književnosti, morda v skladu s procesi rekatolizacije družbe, izide pri katoliških ali kako drugače s (predvsem katoliško) duhovnostjo povezanih založbah. Katoliška založba Družina je tako naročila ponovni prevod klasičnega romana-biografije sv. Jožefa Jana Dobraczyńskega Očetova senca (prev. L. Unuk). Knjiga je namreč prvič izšla v slovenščini z naslovom Rednik: roman o svetem Jožefu v prevodu Franceta Vodnika leta 1980 pri goriški Mohorjevi družbi. Roman, ki življenja nadomestnega Jezusovega očeta ne prikazuje kot idilo, ampak kot stalni duševni boj, ki ga Jožef premaguje $\mathrm{z}$ neskončno vdanostjo, je na dogodbeni ravni in s številnimi realijami trdno vpet v zgodovino Svete dežele. Na platnicah zapisana naklada je 1000 izvodov, kar pove, da lahko ta tradicionalna katoliška založba računa na za slovenske razmere širok krog bralstva. Da gre pri katoliških založbah za enega izmed velikih, dokaj samozadostnih sistemov, ki lahko poskrbijo tudi za plasiranje knjig, ki jih izdajajo, ugotavlja tudi Samo Rugelj. ${ }^{31}$

Založba Logos, pri kateri je izšla zbirka teoloških esejev Wacława Hryniewicza Pričevalci velikega upanja: vesoljno odrešenje v zgodnjekrščanski misli, je naravnana v duhovnost bolj intelektualnega kova. Hryniewicz (1936), upokojeni profesor Katoliške univerze v Lublinu, velja za enega boljših poznavalcev pravoslavja in pashalne teologije. Prevedena knjiga je posvečena apokatastazi v zgodnjekrščanski misli, konceptu, ki izraža upanje na vesoljno odrešenje stvarstva kot celote in je, kot vemo, živo vznemirjal pesnika Czesława Miłosza. Knjigo je prevedla rusistka Urša Zabukovec, poznavalka Dostojevskega ter ruske in poljske duhovne književnosti.

$\mathrm{V}$ zadnjem času dobivajo pomembno funkcijo internetne in radijske objave, ki vse bolj prevzemajo nekdanjo vlogo revialnih. Dostop do objav v tiskanih revijah je namreč vse bolj omejen, čakanje na objavo pa zamudno, zato v manjši meri izpolnjujejo svojo tradicionalno funkcijo sprotnega seznanjanja $\mathrm{z}$ avtorji,

30 Dostopno na: https://www.dobreknjige.si/Knjiga.aspx?knjiga=5537 [obiskano: 16.03 .2018$]$.

31 S. Rugelj, 2018: Postkrizna knjižna produkcija na Slovenskem. »Bukla«, 14/144, str. 3. 
kolikor poleg izvirne sploh še objavljajo tudi prevodno literaturo. Radijske in spletne objave dajejo večjo svobodo prevajalske izbire v širokem diapazonu od klasičnih do najmlajših in alternativnih avtorjev ter omogočajo predstaviti več avtorjev hitreje, kot to zmorejo knjižne ali tudi revialne. Čeprav ne razpolagam s celovitimi podatki o takšnih objavah niti za leto 2017 niti za daljše obdobje, naj zgornjo trditev ponazorim $\mathrm{z}$ delnimi, ki so mi dostopni.

Tako po radiu kot $\mathrm{v}$ spletnih revijah Logos, Locutio in Poiesis (zadnji se specializirata za poezijo) je bilo v obdobju 2016-2018 objavljeno veliko mlajših, slovenskim bralcem še nepoznanih avtorjev kot tudi nekaj klasičnih, ki doslej niso prišli v najožji izbor založb za knjižne izdaje. Tako so bili v Logosu: mednarodni večjezični reviji za kulturo in duhovnost $v$ omenjenem obdobju v prevodih več prevajalcev predstavljeni naslednji pri nas še manj znani mlajši in avtorji srednje generacije: Julia Fiedorczuk, Anna Augustyniak, Małgorzata Lebda, Bronka Nowicka, Marzanna Bogumiła Kielar, od klasičnih avtorjev pa Julia Hartwig, Aleksander Wat, Anna Świrszczyńska. V Locutiu je Katarina Šalamun Biedrzycka v istem obdobju predstavila poezijo Tomasza Mazurja, Marcina Orlińskega, Miłosza Biedrzyckega, M. B. Kielar, Arturja Grabowskega in Stanisława Jerzyja Sita, v Poiesisu pa mdr. Józefa Barana in Jadwige Malina. Tudi radio omogoča sprotno predstavljanje poljskih pesnikov in prozaistov v več različnih prevodnih oddajah. Sama sem po radiu v obdobju 2016-2018 z daljšimi izbori predstavila poezijo Julie Hartwig, Tadeusza Różewicza, Ewe Sonnenberg in Anne Augustyniak, z odlomki iz proznih del pa Wioletto Grzegorzewsko, Kajo Malanowsko, Zośko Papużanko, Patrycjo Pustkowiak, Mariusza Sieniewicza, Ziemowita Szczerka, Krzysztofa Vargo. Poljsko poezijo po radiu že dolga leta predstavlja Katarina Šalamun Biedrzycka, občasno pa tam prevode objavljata tudi Staša Pavlović (npr. Mrożkove humoreske) in Lara Unuk. Menim, da našteta imena dovolj prepričljivo pričajo o pomenu teh aktualnejših poti za predstavljanje novih ali manj poznanih avtorjev ter dopolnjevanje $\mathrm{v}$ prevodu dostopnega dela že znanih, kar ne nazadnje popestri in dodatno osmisli prevajalčevo delo.

\section{Literatura}

Blatnik A., 2011: Bo še šlo brez Nobelove? »Pogledi«, 23. Dostopno na: http:// pogledi.delo.si/knjiga/bo-se-slo-brez-nobelove [obiskano: 1.10.2018].

Blatnik A., 2017a: Prevodno leposlovje v sodobni Sloveniji. »Knjižnica«, 61/4, str. 47-57.

Blatnik A., 2017b: Vredno je, čeprav je brezplačno. »Literatura«, 316/XXIX, str. 116-130. 
Bucka-Kustec K., 2018: Bibliografia przekładów literatury polskiej w Słowenii w 2017 roku. Tipkopis.

Even-Zohar I.: 2009: Miejsce literatury tłumaczonej w polisystemie literackim.

V: P. Bukowski, M. Heydel, ur.: Współczesne teorie przekładu: Antologia.

M. Heydel, prev. Krakov, Znak, str. 197-203.

Heydel M., 2009: Itamar Even-Zohar (ur. 1939). V: P. Bukowski, M. Heydel, ur.:

Współczesne teorie przekładu: Antologia. M. Heydel, prev. Krakov, Znak, str. 196-196.

Izpis iz poljščine prevedenih izdaj iz sistema Cobiss, 2017. Dostopno na:

https://plus.si.cobiss.net/opac7/bib/search/expert?c=la\%3Dslv+and+lo\%3

Dpol+and + py $\% 3 \mathrm{D} 2017^{*} \& \mathrm{db}=$ cobib \&mat $=$ allmaterials\&start $=10$ [obiskano: 20.09.2018].

Jež N., 2017: Nova dinamika slovenskega prevajanja iz poljske književnosti v zadnjih desetletjih. »Jezik in slovstvo", 2-3/LXII, str. 67-75.

Rugelj S., 2018: Postkrizna knjižna produkcija na Slovenskem. »Bukla«, 14/144, str. 3.

Muszyńska Vizintin A., 2016: Przekłady literatury polskiej w Słowenii w 2015 roku. »Przekłady Literatur Słowiańskich«, zv. 7, 2. del, str. 187-198.

\section{Jana Unuk \\ Od romanov do teoloških esejev: pregled slovenskih prevodov poljske literature v letu 2017}

POVZETEK | Članek vsebuje pregled slovenskih prevodov poljske literature v letu 2017 in opozori na nekatere okoliščine izdajanja poljske prevodne literature v Sloveniji. Predstavi posamezne prevodne izbire ter podrobneje razloži nekatere posebnosti pri prevajanju in izdaji predvsem treh del: monumentalnega zgodovinskega romana Jakobove bukve Olge Tokarczuk, klasičnega dela Sanatorij Pri peščeni uri, dopolnjenega z drugimi spisi, modernista Bruna Schulza ter izbora novel poljsko-židovskega, v jidišu pišočega nobelovca I. B. Singerja. Ugotavlja zvrstno raznolikost prevedenega, opozori na prvi prevod mladinskega fantastičnega romana $\mathrm{D}$. Terakowske in na večjo navzočnost katoliških založb. Poudari pomen objav v internetnih revijah in po radiu, ki pomembno dopolnjujejo sliko poljske literature $\mathrm{v}$ očeh slovenskega bralca.

KLJUČNE BESEDE | periferne literature, poljsko-slovenski prevodi 2017, prevajalske izbire, zvrstna raznolikost 


\section{Jana Unuk \\ From Novels to Theological Essays: Review of Slovene Translations of Polish Literature in 2017}

SUMMARY | Slovene and Polish literatures could both be defined as peripheral literatures according to Even-Zohar's understanding of position of translational literature in literary polysystems. Moreover, they tend to be perceived as such by each other's potential readership, which might be a possible explanation of the fact that Slovene translators of Polish literature tend to be rather free in their choices of translated authors and works and less under pressure of expected commercial success than their fellow-translators from bigger languages. In spite of this marginality in each other's literary field, quality literature is continually being translated between both languages, partly because of the trend and politics of stimulating translating among European literatures in European Union. In 2017, 14 works of Polish literature were published in Slovenia, translated by eight translators. Most numerous were novels, among them the third successive European translation of voluminous historical novel The Books of Jacob by Olga Tokarczuk and a juvenile fantasy novel by Dorota Terakowska. Another noticeable trait of 2017 production is its generic diversity: apart from novels, it consists of three short story collections, among them Sanatorium under the Sign of Hourglass by Bruno Schulz, two selections of poetry by contemporary poets, two books for children, theological essays by Wacław Hryniewicz, an authority on Orthodox creed, and one play, translated for the sake of theatre performance in Kranj Theatre. Short translations for internet magazines and Radio Slovenia contribute additional variegation to the corpus of Slovene literary translations, by allowing for more broad translation choices and up-to-date introduction of younger and less canonical authors.

KEYWORDS | peripheral literatures, Polish-Slovene translations in 2017, translation choices, genre diversity

JANA UNUK | tłumaczka, redaktorka, autorka licznych posłowi i innych tekstów o literaturze polskiej. Zajmuje się polską poezją XX i XXI wieku, współczesną polską prozą i twórczością Virginii Woolf. Przetłumaczyła 65 książek dla dorosłych i 47 dla dzieci, w tym pięć antologii baśni ludowych, z literatury polskiej m.in. poezję C. Miłosza, W. Szymborskiej, T. Różewicza, A. Świrszczyńskiej, A. Wata, Z. Herberta, M.B. Kielar, E. Sonnenberg, prozę B. Schulza, O. Tokarczuk, M. Tulli, J. Bator, P. Huellego, S. Chwina, A. Stasiuka, I. Karpowicza, J. Dehnela, M. Łozińskiego, H. Krall, I. Fink, M. Szczygła, G. Herlinga-Grudzińskiego, dramat P. Demirskiego, z angielskiego powieści i opowiadania V. Woolf i I.B. Singera, z bośniackiego D. Karahasana, z serbskiego F. Davida i V. Stevanovicia. W 2006 roku dostała nagrodę im. Antona Sovrè, jest członkinią jury międzynarodowej nagrody literackiej Vilenica. 